\title{
SOBRE EL LENGUAJE EN EL TEATRO ÁRABE ARGELINO (II)
}

\author{
NAIMA BENAICHA ZIANI \\ Universidad de Alicante
}

Desde su creación desde la época de la colonización, el teatro argelino ha conocido una evolución notable. A lo largo de la historia nacieron varias troupes $^{1}$, se crearon muchas obras para representar la Argelia colonial, la revolucionaria, luego la independiente, para narrar la Argelia desencantada, la Argelia que sufre el terrorismo y por fin para mostrar la Argelia contemporánea que se esfuerza por salir de los dogmas, de la censura y del discurso oficialmente impuesto.

En este mismo contexto se muestra, igualmente, valiente, y trata temas espinosos que conciernen a todas las capas sociales. Tiene por lema defender la causa de la libertad individual, las injusticias sociales, la desigualdad entre hombres y mujeres, la corrupción, la educación, los dogmas religiosos y también el papel de la mujer en la sociedad argelina. Son por excelencia temas que todos los dramaturgos argelinos abordan en sus textos. Unos en francés y otros en árabe dialectal argelino o en tamazight ${ }^{2}$, las dos, lenguas autóctonas del norte de África.

Durante largas décadas, especialmente las que siguieron a la independencia de Argelia, figuras como Assia Djebar o Kateb Yacine, continuaban escribiendo los textos dramatúrgicos en la única lengua que manejaban: el francés. Entrada ya la década de los 70 y por la necesidad y urgencia por construir una sociedad civil consolidada, un grupo de intelectuales decide abrir el debate y hablar sobre el porvenir de las lenguas en este país. La identidad del pueblo argelino peligraba y, por estar estrechamente relacionada con el uso de la lengua, había que tomar decisiones apresuradamente.

Liderados por el premiado escritor Kateb Yacine, en 1970 un grupo de intelectuales y dramaturgos crea una troupe de teatro a la que le pone

1 Según la RAE, son una compañía de artistas, especialmente de teatro, danza, cine o circo que trabajan juntos, desplazándose de un lugar a otro.

2 Según el Diccionaire berbère, es la lengua de una franja geográfica que va desde Marruecos hasta Egipto. Cuarenta variedades derivan de este idioma, siendo su alfabeto el llamado tafinagh. 
el nombre de "l'Action Cultuelle des Travailleurs" (ACT), acción cultural de los trabajadores, queriendo así implicar a la masa obrera, siempre la más afligida. Aprovechando que la troupe creada estaba avalada por el Ministerio de Trabajo de entonces, los intelectuales reunidos proponen convertir tanto el árabe argelino como el tamazight en lenguas de la expresión dramática, por ser estas dos últimas lenguas las que maneja en su día a día la mayoría de la población argelina. Eran y siguen siendo, por excelencia, el vehículo de comunicación más usado.

Más allá de la escritura, y a pesar de las controversias que podían generar, los dramaturgos insistían en expresar su deseo de recopilar y traducir al árabe argelino y al tamazight todas las obras escritas en francés por dramaturgos argelinos, antes, durante y después de la colonización. Ver traducidas a las dos lenguas vernáculas todas las obras escritas en la lengua de Baudelaire era un sueño que todos quisieron convertir en realidad. Y así lo hicieron, empezando por traducir L'Homme aux sandales de caoutchouc, del dramaturgo Kateb Yacine.

El teatro, a través de sus textos dramatúrgicos escritos en francés, especialmente los que tratan temas afectados por el postcolonialismo, deja claro lo difícil e incómodo que es expresar en un idioma prestado inquietudes y sentimientos de una cultura con lengua propia. La identidad híbrida de estos autores queda más que reflejada. Tanto el teatro como la literatura escritos en francés, han conocido y siguen conociendo este malestar, el de vivir entre dos o tres lenguas y, por ende, culturas. En sus inicios, los dramaturgos se limitaban a traducir textos pensados en argelino pero escritos en francés. Y, aprovechando que la hibridación es un proceso de interacción entre lo local y lo global, los dramaturgos argelinos, como Allalou, Bachtarzi, Kateb Yacine y Abdelkader Alloula, durante las décadas 60, 70, 80 y 90 pusieron un especial interés en compartir sus obras escritas en francés con el público argelino, traduciéndolas a la lengua de este último.

En cambio, hoy en día y bajo los escombros de una crisis que sopla sobre el país, textos nuevos ven la luz, escritos por dramaturgos que encuentran su sitio en la herencia de los autores citados, convertidos ya en clásicos. No obstante, se desmarcan de éstos aportando un estilo, una escritura nueva, usando indistintamente, el árabe argelino, el tamazight o el francés. 